\title{
XXXIII. Reply to the inquiry in the supplement number of the philosophical magazine for January 1842 , respecting a manuscript at Oxford on the rectification of the circle
}

\section{William Rutherford Esq.}

To cite this article: William Rutherford Esq. (1842) XXXIII. Reply to the inquiry in the supplement number of the philosophical magazine for January 1842, respecting a manuscript at Oxford on the rectification of the circle , Philosophical Magazine Series 3, 20:130, 229-230, DOI: $10.1080 / 14786444208650557$

To link to this article: http://dx.doi.org/10.1080/14786444208650557

曲 Published online: 01 Jun 2009.

Submit your article to this journal ¿

Џ Article views: 2

Q View related articles $\sqsubset$ 
increased by the insertion into the spiral of a bundle of iron wires, but, on the contrary, diminished by a bar of iron. The thermic action is diminished in both cases, but that of magnetizing steel increased; the current'so induced behaves therefore exactly like that induced in another wire.

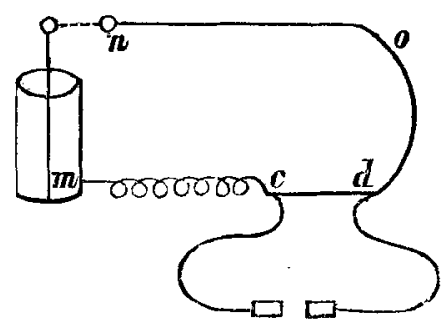

\section{On the Magnetism of the so-called Unmagnetic Metals.}

We have as yet endeavoured to prove the magnetism of the so-called unmagnetic metals by attempting to direct or attract them by strong magnets, or else by trying their power of moving very light delicate magnetic needles; both methods however without success. In the above experiments we have demonstrated the hindering influence of the electrical currents induced in iron during its magnetization, and this excited a hope of being able to let the weak magnetism of these metals appear, by preventing the formation of those electric currents. This was crowned with complete success; for while massive bars of antimony, bismuth, lead, tin, zinc, copper and brass weakened the current $\alpha \beta$, so that when the equilibrium was destroyed, a magnetic needle indicated the direction of the current as being from $\beta$ to $\alpha$; on the contrary, the current was strengthened, or the direction became froin $\alpha$ to $\beta$ when those substances were introduced into the spiral $a b$ in the form of well-isolated wires.

XXXIII. Reply to the Inquiry in the Supplement Number of the Philosophical Magazine for January 1842, respecting a Manuscript at Oxford on the Rectification of the Circle. By William Rutherford, Esq.*

I the Supplement Number of the Philosophical Magazine for January 1842, Mr. Halliwell inquires whether I can give him any information respecting a manuscript at Oxford, said to contain the computation of the ratio of the diameter of a circle to its circumference to 154 places of figures.

I have not seen the manuscript to which I have alluded in my paper on the Rectification of the Circle in the Philosophical Transactions; but I have no doubt whatever that such a manuscript does exist, and my belief is strengthened by the fact that the figures in the ratio are there correctly computed

\footnotetext{
* Communicated by the Author.
} 


\section{Prof. De Morgan on Fernel's Measure of a Degree,}

as far as 152 places, the extent to which I have verified the approximation. This manuscript is also alluded to by the writer* of the article, "Quadrature of the Circle," in the Penny Cyclopædia, vol. xix. No. 1190, p. 187 ; and if $\mathrm{Mr}$. Halliwell will look into that article he will find it there stated, that Baron Zach informed Montucla that he had seen a manuscript in the Radcliffe Library, at Oxford, in which the ratio of the diameter of a circle to its circumference was carried to 154 places. Professor Davies, of the Royal Military Academy, in his twelfth edition of Hutton's Course of Mathematics, vol. i. p. 476, also refers to the Oxford approximation, probably from the same source as myself, viz. that of the Penny Cyclopædia. Should Mr. Halliwell be successful in his search in the Radcliffe Library, it is to be hoped that he will publish an analysis of the contents of this curious manuscript, and give the method of procedure adopted for the accomplishment of such a laborious task as the computation of the ratio of the diameter to the circumference to 154 places of figures.

Royal Military Academy, Woolwich, January 28, 1842 .

XXXIV. On Fernel's Measure of a Degree, in reply to Mr. Galloway's Remarks. By Professor De Mongan.

To the Editors of the Philosophical Magazine and Journal.

\section{Gentremen,}

IN making some reply to the remarks which Mr. Galloway has made on my correction (as I am obliged still to maintain it to be) of Montucla and Delambre (or Lalande), I must first express my gratification at the subject having been taken up with so much research.

The question between Mr. Galloway and myself lies in little compass : he contends for the geometrical foot of Fernel being the French foot of the day: I maintain this to be unlikely in itself, as being contrary to usual practice, and wholly inadmissible, as by implication making Fernel declare that the step of an ordinary man was more than 38 English inches. As this last point however is a new one, raised by me in my second letter (of last month), I will here confine myself to the first point, namely, as to the question whether the geometrical foot is to be taken to be the French foot.

I will also omit all question as to whether the French foot

* Probably Professor De Morgan. 